\title{
Predatory viability of the nematophagous fungus Duddingtonia flagrans on the infective larvae of gastrointestinal nematodes of sheep following storage and refrigeration
}

\author{
Viabilidade predatória do fungo nematófago Duddingtonia flagrans \\ sobre larvas infectantes de nematódeos gastrintestinais de ovinos após \\ armazenamento e refrigeração
}

\author{
Vinicius Longo Ribeiro Vilela ${ }^{1,2}$ (D); Paulo Wbiratan Lopes da Costa ${ }^{2}$; Francisca Flávia da Silva ${ }^{3}$; \\ Hermano Manoel Francisco Figueiredo Bezerra ${ }^{1}$; Leonardo Vinícius Silva de Oliveira ${ }^{1}$; Maysa de Oliveira Dantas ${ }^{1}$; \\ Thais Ferreira Feitosa ${ }^{1}$; Jackson Victor de Araújo ${ }^{4}$; Fabio Ribeiro Braga ${ }^{5}$ \\ ${ }^{1}$ Instituto Federal da Paraíba, Departamento de Medicina Veterinária, Sousa - PB, Brazil \\ ${ }^{2}$ Universidade Federal de Campina Grande, Programa de Pós-graduação em Ciência Animal, Patos - PB, Brazil \\ ${ }^{3}$ Universidade Federal de Campina Grande, Programa de Pós-graduação em Medicina Veterinária, Patos - PB, Brazil \\ ${ }^{4}$ Universidade Federal de Viçosa, Departamento de Medicina Veterinária, Viçosa - MG, Brazil \\ ${ }^{5}$ Universidade Vila Velha, Departamento de Medicina Veterinária, Vila Velha - ES, Brazil
}

\begin{abstract}
The objective of this study was to evaluate the in vivo predatory viability of the nematophagous fungus, Duddingtonia flagrans, after storage (36 months) and refrigeration $\left(2-8{ }^{\circ} \mathrm{C}\right)$. This viability was evaluated using the infective larvae of gastrointestinal nematodes of sheep in the Northeastern semi-arid region of Brazil. Sixteen Santa Inês sheep with negative counting of eggs per gram of feces (EPG) were divided into four experimental groups, each group comprised of four animals. The pellets were administered at the dose of $3 \mathrm{~g} / 10 \mathrm{~kg}$ of live weight ( $20 \%$ fungal micelyum), and a single administration was performed for each animal. Group I was administered pellets that had been stored for 36 months; Group II, freshly produced pellets; Group III, freshly produced pellets that did not contain fungi; and Group IV, pellets were not administered, and this was the control group. Feces were collected for 5 days, every $24 \mathrm{~h}$ for analysis. There was a significant decrease in the number of infective larvae of sheep nematodes that received $D$. flagrans pellets in a sodium alginate matrix, $82 \%$ was observed for Group I and $71 \%$ for Group II, compared to the control group. It is therefore concluded that the fungus, $D$. flagrans, pelleted in sodium alginate matrix after 36 months of storage at $2-8^{\circ} \mathrm{C}$, showed efficacy in reducing the number of infective larvae of gastrointestinal nematodes of sheep.
\end{abstract}

Keywords: Nematophagous fungi. Predation. Sheep farming. Time.

\section{RESUMO}

O objetivo deste trabalho foi avaliar a viabilidade predatória in vivo do fungo nematófago Duddingtonia flagrans, após armazenamento (36 meses) e refrigeração $\left(2-8^{\circ} \mathrm{C}\right)$. Esta viabilidade foi avaliada utilizando larvas infectantes de nematódeos gastrintestinais de ovinos no semi-árido nordestino do Brasil. 16 ovinos Santa Inês com contagem negativa de ovos por grama de fezes (GEP) foram divididos em quatro grupos experimentais, compostos por quatro animais. Os péletes foram administrados na dose de $3 \mathrm{~g} / 10 \mathrm{~kg}$ de peso vivo ( $20 \%$ de micélio fúngico), e uma única administração foi realizada para cada animal. Grupo I foi administrado péletes que foram armazenados por 36 meses; Grupo II, péletes recém-produzidos; Grupo III, péletes recém-produzidos que não continham fungos; e o Grupo IV, péletes não foram administrados, e este foi o grupo controle. As fezes foram coletadas por cinco dias, a cada 24 horas, para análise. Houve uma diminuição significativa no número de larvas infectantes de nematóides ovinos que receberam pellets de $D$. flagrans, $82 \%$ foi observado para o Grupo I e $71 \%$ para o Grupo II, comparado ao grupo controle. Conclui-se, portanto, que o fungo $D$. flagrans, peletizado em matriz de alginato de sódio após 36 meses de armazenamento a $2-8{ }^{\circ} \mathrm{C}$, apresenta eficácia na redução do número de larvas infectantes de nematódeos gastrintestinais de ovinos.

Palavras-chave: Fungos nematófagos. Predação. Criação de ovelhas. Tempo. 


\section{Correspondence to:}

Vinicius Longo Ribeiro Vilela

Instituto Federal da Paraíba, Departamento de Medicina

Veterinária

Av. Tancredo Neves, s/n, Jardim Sorrilândia

CEP: 58800-970, Sousa - PB, Brazil

e-mail: vinicius.vilela@ifpb.edu.br

Received: February 01, 2019

Approved: May 09, 2019

How to cite: Vilela VLR, Costa PWL, Silva FF, Bezerra HMFF, Oliveira LVS, Dantas MO, Feitosa TF, Araújo JV, Braga FR. Predatory viability of the nematophagous fungus Duddingtonia flagrans on the infective larvae of gastrointestinal nematodes of sheep following storage and refrigeration. Braz J Vet Res Anim Sci. 2019;56(3):e154252. https://doi.org/10.11606/issn.1678-4456.bjvras.2019.154252

\section{Introduction}

Sheep farming is a significant and diversified economic activity carried out in several continents. In most cases, it is extensively and empirically developed and carried out in regions with diverse vegetation types and climates (Vieira et al., 2014). The sheep herd in Brazil is estimated at 18.4 million animals, of which 11.6 million are in the Northeast Region (Instituto Brasileiro de Geografia e Estatística, 2016).

The search for alternatives for the control of gastrointestinal nematodes in small ruminants has been broadening, as indicated by studies using biological control for nematophagous fungi (Araújo, 2009; Melo et al., 2003; Vilela et al., 2016). A series of studies that may aid in overcoming some obstacles in the routine use of biological control agents recognized for their fungal predatory activity in ruminant breeding are required. Among them, we can mention: (a) the laboratory maintenance time for the nematophagous fungi isolates; and (b) the maintenance of their viability with increasing storage time. Therefore, for almost a decade, several researchers have studied and elucidated mechanisms and developed materials to analyze the aforementioned factors in order to determine the predatory viability of nematophagous fungi with respect to their storage time (Araújo et al., 2007; Paz-Silva et al., 2011; Silveira et al., 2017).

When the nematophagous fungal pellets in a sodium alginate matrix are administered orally, they pass through the gastrointestinal tract. From $21 \mathrm{~h}$ post-administration, they produce traps in the feces, presenting practical applications, where they capture the nematodes, killing them by the destruction of internal organs (Melo et al., 2003).
The pellets containing nematophagous fungi can be excreted in the feces for up to $120 \mathrm{~h}$ (Araújo, 2009). As a form of biological control, the use of $3 \mathrm{~g}$ of pellets containing $0.6 \mathrm{~g}$ of Duddingtonia. flagrans mycelium for every $10 \mathrm{~kg}$ of live weight was shown to be effective in small ruminants (Vilela et al., 2012). Studies discussing the time and consequence of storage and refrigeration on the viability of this fungus after pelletizing in alginate matrix are scarce.

Thus, the objective of the present study was to evaluate in vivo the degree of viability of the fungus $D$. flagrans following storage and refrigeration on the infective larvae of gastrointestinal nematodes of sheep in the semi-arid region of Northeast Brazil.

\section{Materials and Methods}

This research was submitted and approved by the Ethics and Research Committee, Federal University of Campina Grande and obtained number CEP - 098.2017.

\section{Fungi and mycelial mass production}

The AC001 isolate of D. flagrans (AC001), stored at the Parasitology Laboratory of the Veterinary Department - DVT, Federal University of Viçosa - UFV, Minas Gerais, Brazil, was used in this study. This isolate was obtained from the soil in the municipality of Viçosa, MG. Fungal mycelia were obtained by transferring culture discs (petri discs approximately $4 \mathrm{~mm}$ in diameter) from fungal isolates (D. flagrans) in $2 \%$ water agar (2\% WA) to $250 \mathrm{~mL}$ Erlenmeyer flasks containing $150 \mathrm{~mL}$ of GPY liquid medium (glucose, sodium peptone, and yeast extract), and then incubated in the dark at $26^{\circ} \mathrm{C}$ for 10 days with shaking at $120 \mathrm{rpm}$. After this period, the mycelia were removed, filtered and weighed on an analytical balance. All procedures followed were in accordance with the methodology of Araújo et al. (2010). The mycelium was then removed for pelletization using sodium alginate as described by Walker \& Connick (1983) and modified by Lackey et al. (1993). The pellet fungal micelyum concentration was $20 \%$.

\section{Experimental tests}

The experiments were performed at the Experimental Farm of the Veterinary Hospital of the Federal Institute of Paraíba (IFPB), Sousa, Paraíba State, Brazil. The study used pellets of $D$. flagrans (AC001) encapsulated in sodium alginate matrix and stored in plastic bags at $2-8{ }^{\circ} \mathrm{C}$ in the dark for 36 months and freshly produced pellets.

For the production of infective larvae to be added in the experimental assay, feces were collected directly from the rectum of 16 Santa Inês sheep, confined, aged between 
1 and 2 years, averaging $40 \mathrm{~kg}$ live weight, and then sent (EGPB) for the counting of eggs per gram of feces - EPG (Gordon \& Whitlock, 1939), presenting an average of $1200 \pm 376$. Subsequently, coprocultures were performed (Roberts \& O'Sullivan, 1950) and larvae recovered by Bearmann method (Willcox \& Coura, 1989). Ueno \& Gonçalves (1994) methodology was used for quantification and identification of infective larvae. The genera present in the coprocultures were Haemonchus sp. (81\%), Trichostrongylus spp. (12\%) and Oesophagostomum (7\%).

After larvae production, the animals were dewormed (levamisole hydrochloride $5 \%, 1.0 \mathrm{~mL} / 10 \mathrm{~kg}$ of live weight). Ten days after vermifugation, other EPG were performed, resulting in parasite absence, forming four experimental groups, each containing four animals. Group I received pellets containing $D$. flagrans stored for 36 months at a dosage of $3 \mathrm{~g}$ pellets $/ 10 \mathrm{~kg}$ live weight with a single administration for each animal; Group II received freshly produced pellets containing $D$. flagrans at a dosage of $3 \mathrm{~g}$ of pellets $/ 10 \mathrm{~kg}$ of live weight with a single administration per animal; Group III, each animal received $3 \mathrm{~g}$ of freshly produced pellets without fungi/ $10 \mathrm{~kg}$ live weight; and Group IV did not receive pellets, and constituted the control group. During each individual administration, $100 \mathrm{~g}$ of commercial sheep feed was added to facilitate ingestion. The animals were submitted to a complete diet, corn-based, soybean meal, Andrequicé grass hay (Leersia hexandra S. W.) and complete mineral mixture, in order to meet nutritional requirements for sheep, according to National Research Council (1985).
During a 5-d period, sheep feces were collected at every $24 \mathrm{~h}$ time-point $(24,48,72,96$, and $120 \mathrm{~h})$ and sent to VPL/ IFPB, to perform the analyses. For coprocultures, five replicates were performed for each group according to collection times, prepared by mixing $15 \mathrm{~g}$ of feces from each animal and $5 \mathrm{~g}$ of expanded vermiculite (Roberts \& O'Sullivan, 1950), and 1000 infective larvae (L3) from gastrointestinal nematodes of sheep, naturally infected, were further added. Subsequently, the coprocultures were incubated for $7 \mathrm{~d}$ at $28^{\circ} \mathrm{C}$. After this period, the $\mathrm{L} 3$ of the coprocultures were recovered by the Baermann method (Willcox \& Coura, 1989), quantified, and then identified under an optical microscope $(100 \times$ magnification), according to protocol of Ueno \& Gonçalves (1994).

The percentage of larval reduction was determined, according to the methodology established by Mendoza-de-Guives et al. (1999): Reduction (\%) = Mean L3 recovered from the control group - Mean of L3 recovered from the treated group $\times 100$ / average L3 recovered from the control group. The data were subjected to analysis of variance (F test), and then the means were compared using the Tukey test at the $1 \%$ probability level via Biostat 3.0 software (Ayres et al., 2003).

\section{Results and Discussion}

There was a significant reduction in the larval recovery $(\mathrm{p}<0.01)$ in the groups that received pellets containing D. flagrans (Group I- pellets stored for 36 months and Group 2- freshly prepared pellets) during the 24-96h period following pellet administration (Figure 1), with reduction in larval number of up to $82 \%$ in Group I and

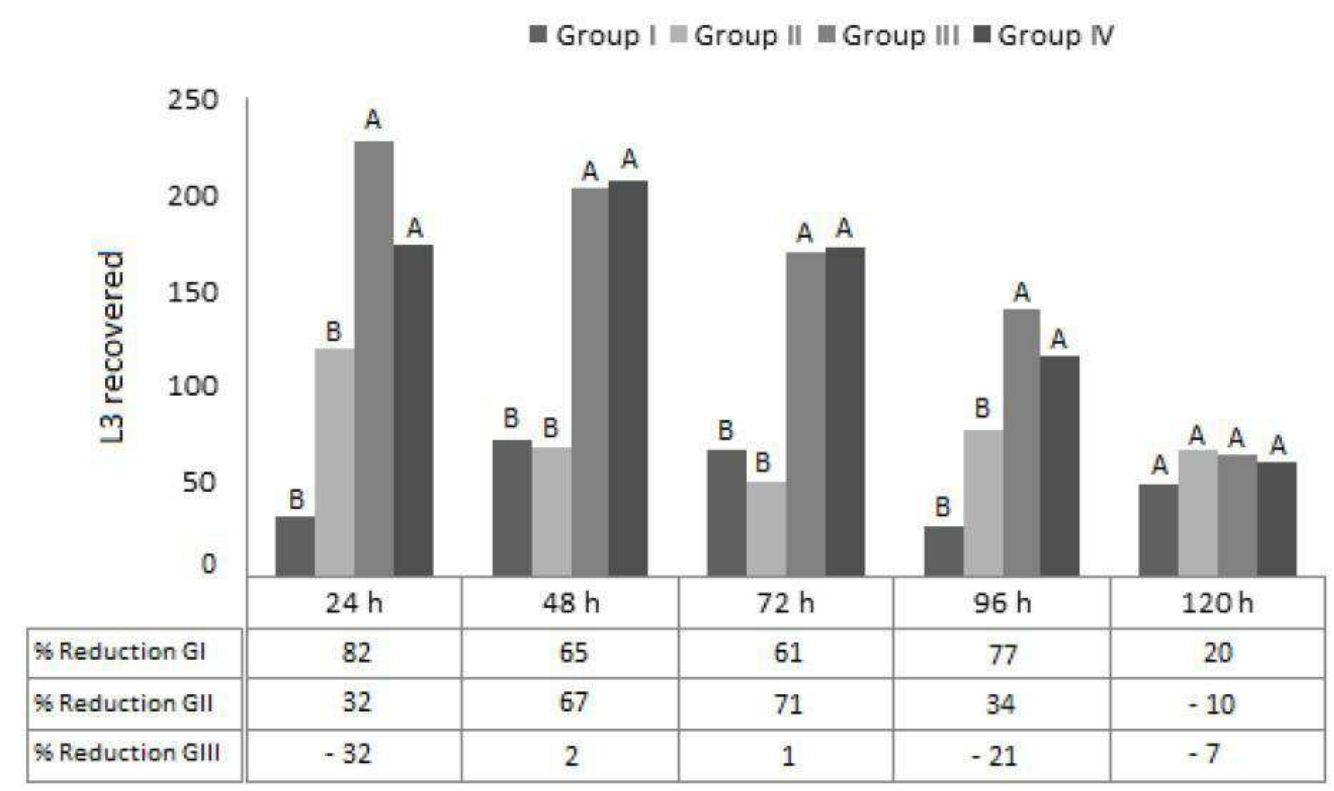

Figure 1-Mean and percentage of reduction in the number of the infective larvae of sheep nematodes recovered from coprocultures: Group I = pellets with D. flagrans - 36 months of storage; Group II = pellets with D. flagrans - freshly produced; Group III = pellets without fungi; Group IV = did not receive pellets, control. Different letters for the same time interval indicate statistically significant differences in the groups, as determined by the Tukey’s test with a probability level of $1 \%$. 
$71 \%$ in Group II. Braga et al. (2011) observed a reduction of $88.6 \%$ in the number of infective cyathostome larvae of horses when compared to the control group using the AC001 isolate stored on silica gel for 7 years. There are no studies evaluating the predatory efficacy of pelleted nematophagous fungi in sodium alginate post-storage.

It was observed that the peak of larval predation was at $24 \mathrm{~h}$ in Group I and $72 \mathrm{~h}$ in Group II (Figure 1). Studies have shown that the time of passage of the pellets through the gastrointestinal tract varies, according to the animal species. After administration, the fecal release of the pellets is initiated after about $24 \mathrm{~h}$ and continues for up to at least $96 \mathrm{~h}$ (Araújo et al., 1999; Fernandes et al., 2017; Ferreira et al., 2011; Kolb, 1984; Melo et al., 2003; Rédua et al., 2002). Tavela et al. (2013) observed high reductions in the number of infective larvae of equine cyathostomes between $12 \mathrm{~h}$ and $72 \mathrm{~h}$ after the respective administration of pellets of D. flagrans and Monacrosporium thaumasium.

Since there was no statistical difference $(\mathrm{p}>0.01)$ with respect to the recovery of larvae from the coprocultures between Group III (pellets without fungi) and Group IV (control; Figure 1), we can infer that the pellet formulation of sodium alginate did not interfere in its larval predation activity, thereby, reinforcing the suitability of the sodium alginate pellets for the administration of nematophagous fungi to animals, as observed in several studies (Braga et al., 2010; Fernandes et al., 2017; Tavela et al., 2011; Vilela et al., 2016). In addition, refrigeration at $2-4^{\circ} \mathrm{C}$ did not interfere with the predation ability of the fungus.

In the coprocultures, the members of the genus Haemonchus were predominantly observed, constituting $78 \%$ of the infective larvae (Table 1). The second most prevalent were the Trichostrongylus spp., followed by members of the genus

Table 1 - Percentage of infective larvae of gastrointestinal nematodes recovered from coprocultures

\begin{tabular}{lccccccc}
\hline Groups & & $\mathbf{0 ~ h}$ & $\mathbf{2 4} \mathbf{h}$ & $\mathbf{4 8} \mathbf{h}$ & $\mathbf{7 2} \mathbf{h}$ & $\mathbf{9 6} \mathbf{h}$ & $\mathbf{1 2 0} \mathbf{h}$ \\
\hline Group I & H & 79 & 78 & 92 & 75 & 90 & 80 \\
& T & 16 & 21 & 6 & 15 & 10 & 20 \\
& O & 5 & 1 & 2 & 10 & 0 & 0 \\
Group II & H & 73 & 56 & 78 & 88 & 71 & 80 \\
& T & 20 & 27 & 16 & 6 & 13 & 8 \\
& O & 7 & 18 & 6 & 6 & 16 & 2 \\
Group III & H & 69 & 75 & 70 & 82 & 70 & 90 \\
& T & 23 & 22 & 30 & 18 & 20 & 6 \\
& O & 8 & 3 & 0 & 0 & 10 & 4 \\
Group IV & H & 90 & 68 & 94 & 86 & 74 & 80 \\
& T & 10 & 25 & 6 & 14 & 15 & 14 \\
& O & 0 & 7 & 0 & 0 & 11 & 6
\end{tabular}

Group I = pellets containing $D$. flagrans -36 months of storage; Group II = pellets containing D. flagrans - freshly produced; Group III = pellets without fungi; Group IV = did not receive pellets, control; $\mathrm{H}=$ Haemonchus sp.; $\mathrm{T}=$ Trichostrongylus spp.; $\mathrm{O}=$ Oesophagostomum $\mathrm{sp}$.
Oesophagostomum. The high prevalence of Haemonchus sp. (79.9\%) in coprocultures of sheep in the Northeastern semi-arid region was also observed by Vieira et al. (2014). The high prevalence of $H$. contortus may possibly be because of its high biotic potential that may aid in rapid development of resistance to drugs (Echevarria \& Trindade, 1989).

Braga \& Araújo (2014) reported that the long-lasting preservation of the predatory activity of nematophagous fungi isolates is a basic requirement (necessity) for the success of this type of control. In their study, they evaluated the predatory ability of another nematode-predator isolate Arthrobotrys robusta (isolated I-31) preserved in silica gel for 7 years in the laboratory.

In the present study, D. flagrans was maintained by encapsulation in sodium alginate pellets. The authors believe that these results are in accordance with the in vitro work cited above. However, attention should be drawn to the set of external variables that may influence the results when experiments are carried out in vivo; one such variable evaluated in this study was storage time, and the predatory viability of $D$. flagrans was remarkably high when the storage period was 36 months, and in that case, the 36-month storage period demonstrated excellent viability. The present study draws attention to the main issue of biological control with nematophagous fungi. According to Gronvold et al. (1996), for an isolate to be considered industrially viable, it must undergo the action of the gastrointestinal tract of ruminants.

This research is the first report on the evaluation of the after storage predatory activity of a nematode-predator pelleted in sodium alginate. The results demonstrate that storage for 36 months by refrigerating between $2-8^{\circ} \mathrm{C}$ after D. flagrans (AC001) pelletizing did not affect its predatory activity, thereby, demonstrating high potential for future commercialization.

\section{Conflict of Interest}

On behalf of all authors, the corresponding author states that there is no conflict of interest.

\section{Ethics Statement}

All authors have been personally and actively involved in the manuscript, and are jointly and individually responsible for their content.

\section{Acknowledgements}

The authors would like to thank the Laboratory of Veterinary Parasitology of the Veterinary Hospital Adílio Santos Azevêdo, Instituto Federal da Paraíba, for providing the necessary structure for this research. 


\section{References}

Araújo JM, Araújo JV, Braga FR, Carvalho RO. In vitro predatory activity of nematophagous fungi and after passing through gastrointestinal tract of equine on infective larvae of Strongyloides westeri. Parasitol Res. 2010;107(1):103-8. http://dx.doi.org/10.1007/s00436-010-1841-y. PMid:20369256.

Araujo JV, Rodrigues MLA, Silva WW, Vieira LS. Controle biológico de nematóides gastrintestinais de caprinos em clima semi-árido pelo fungo Monacrosporium thaumasium. Pesqui Agropecu Bras. 2007;42(8):1177-81. http://dx.doi. org/10.1590/S0100-204X2007000800015.

Araújo JV, Stephano MA, Sampaio WM. Passage of nematodetrapping fungi through the gastrointestinal tract of calves. Vet Arh. 1999;69:69-78.

Araújo JV. Controle biológico de helmintos gastrintestinais de caprinos e ovinos por fungos nematófagos. In: Cavalcante ACR, Vieira LSV, Chagas ACS, Molento MB, editors. Doenças parasitárias de caprinos e ovinos: epidemiologia e controle. Brasília: EMBRAPA; 2009. p. 402-25.

Ayres M, Ayres JRM, Ayres DL, Santos AS. Aplicações estatísticas nas áreas de ciências biológicas. Brasília: $\mathrm{CNPq}$; 2003. $290 \mathrm{p}$.

Braga FR, Araújo JV. Nematophagous fungi for biological control of gastrointestinal nematodes in domestic animals. Appl Microbiol Biotechnol. 2014;98(1):71-82. http://dx.doi. org/10.1007/s00253-013-5366-z. PMid:24265027.

Braga FR, Araújo JV, Araujo JM, Tavela AO, Ferreira SR, Freitas Soares FE, Benjamin LA, Frassy LN. Influence of the preservation period in silica-gel on the predatory activity of the isolates of Duddingtonia flagrans on infective larvae of cyathostomins (Nematoda: cyathostominae). Exp Parasitol. 2011;128(4):460-3. http://dx.doi.org/10.1016/j. exppara.2011.05.013. PMid:21627962.

Braga FR, Araújo JV, Silva AR, Carvalho RO, Araujo JM, Ferreira SR, Benjamin LA. Predatory activity of the nematophagous fungus Duddingtonia flagrans on horse cyathostomin infective larvae. Trop Anim Health Prod. 2010;42(6):1161-5. http://dx.doi.org/10.1007/s11250-0109542-1. PMid:20213221.

Echevarria FAM, Trindade GNP. Anthelmintic resistance by Haemonchus contortus to ivermectin in Brazil. Vet Rec. 1989;124(6):147-8. PMid:2929090.
Fernandes FM, Aguiar AR, Costa SLP, Senna T, Mello INK, Oliveira T, Freitas SG, Ferreira WS, Braga FR, Araújo JV. Biological control on gastrointestinal nematodes in cattle with association of nematophagous fungi. Biocontrol Sci Technol. 2017;12(12):1-9. http://dx.doi.org/10.1080/0958 3157.2017.1406063.

Ferreira SR, Araújo JV, Braga FR, Araujo JM, Fernandes FM. In vitro predatory activity of nematophagous fungi Duddingtonia flagrans on infective larvae of Oesophagostomum spp after passing through gastrointestinal tract of pigs. Trop Anim Health Prod. 2011;43(8):1589-93. http://dx.doi. org/10.1007/s11250-011-9848-7. PMid:21626065.

Gordon HM, Whitlock HV. A new technique for counting nematode eggs in sheep faeces. J Counc Sci Ind Res. 1939;12:50-2.

Gronvold J, Henriksen SA, Larsen M, Nansen P, Wolstrup J. Aspects of biological control with special reference to arthropods, protozoans and helminths of domesticated animals. Vet Parasitol. 1996;64(1-2):47-64. http://dx.doi. org/10.1016/0304-4017(96)00967-3. PMid:8893463.

IBGE: Instituto Brasileiro de Geografia e Estatística. Epi Info [Internet]. 2016 [cited 2017 Dec 8]. Available from: http://www.ibge.gov.br

Kolb E. Fisiologia veterinária. Rio de Janeiro: Guanabara Koogan; 1984. 486 p.

Lackey BA, Muldoon AE, Jaffee BA. Alginate pellet formulation of Hirsutella rossiliensis for biological control of plant-parasitic nematodes. Biol Control. 1993;3(2):15560. http://dx.doi.org/10.1006/bcon.1993.1023.

Melo LM, Bevilaqua CML, Araújo JV, Melo ACFL. . Atividade predatória do fungo Monacrosporium thaumasium contra o nematóide Haemonchus contortus, após passagem pelo trato gastrintestinal de caprinos. Cienc Rural. 2003;33(1):16971. http://dx.doi.org/10.1590/S0103-84782003000100028.

Mendoza-De-Guives P, Davies KG, Clarck SJ, Behnke JM. Predatory behaviour of trapping fungi against srf mutants of Caenorhabditis elegans and different plant and animal parasitic nematodes. Parasitology. 1999;119(1):95-104. http:// dx.doi.org/10.1017/S0031182099004424. PMid:10446708. 
NRC: National Research Council. Nutrient requirements of domestics animals: nutrient requeriments of sheep. Washington: National Academy Press; 1985. p. 91.

Paz-Silva A, Francisco I, Valero-Coss RO, Cortiñas FJ, Sánchez JA, Francisco R, Arias M, Suárez JL, López-Arellano ME, Sánchez-Andrade R, De Gives PM. Ability of the fungus Duddingtonia flagrans to adapt to the cyathostomin egg-output by spreading chlamydospores. Vet Parasitol. 2011;179(13):277-82. http://dx.doi.org/10.1016/j.vetpar.2011.02.014. PMid:21402449.

Rédua CRO, Siciliano S, Mujica F, Araujo JV, Rodrigues MLA. Passagem do fungo nematófago Monacrosporium thaumasium pelo trato gastrointestinal de eqüinos. Ciênc Anim. 2002;12:127-30.

Roberts FHS, O'Sullivan JP. Methods of egg counts and laval cultures for strongyles infesting the gastrointestinal tract of cattle. Aust J Agric Res. 1950;1(1):99-102. http:// dx.doi.org/10.1071/AR9500099.

Silveira WF, Oliveira GD, Braga FR, Carvalho LM, Domingues RR, Silva LA, Zanuncio JC, Araújo JV. Predation rate of nematophagous fungi after passing through the gastrointestinal tract of goats. Small Rumin Res. 2017;147:101-5. http:// dx.doi.org/10.1016/j.smallrumres.2016.12.025.

Tavela AO, Araújo JV, Braga FR, Silva AR, Carvalho RO, Araujo JM, Ferreira SR, Carvalho GR. Biological Control of cyathostomin (Nematoda:Cyathostominae) with nematophagous fungus Monacrosporium thaumasium in Tropical Southeastern Brazil. Vet Parasitol. 2011;175(12):92-6. http://dx.doi.org/10.1016/j.vetpar.2010.09.035. PMid:21035270.

Tavela AO, Araújo JV, Braga FR, da Silveira WF, Dornelas e Silva VH, Carretta M Jr, Borges LA, Araujo JM, Benjamin LA, Carvalho GR, Paula AT. Coadministration of sodium alginate pellets containing the fungi Duddingtonia flagrans and Monacrosporium thaumasium on cyathostomin infective larvae after passing through the gastrointestinal tract of horses. Res Vet Sci. 2013;94(3):568-72. http://dx.doi. org/10.1016/j.rvsc.2012.11.011. PMid:23274060.
Ueno H, Gonçalves PC. Manual para diagnóstico das helmintoses de ruminantes. Tokyo: Japan International Cooperation Agency; 1994.

Vieira VD, Vilela VLR, Feitosa TF, Athayde ACR, Azevedo SS, Souto DVO, Silveira GL, Melo LRB. Sheep gastrointestinal helminthiasis in the Sertão region of Paraíba State, Northeastern Brazil: prevalence and risk factors. Rev Bras Parasitol Vet. 2014;23(4):488-94. http://dx.doi.org/10.1590/ s1984-29612014089. PMid:25517527.

Vilela VLR, Feitosa TF, Braga FR, Araújo JV, Santos A, Morais DF, Souto DVO, Athayde ACR. Coadministration of nematophagous fungi for biological control over gastrointestinal helminths in sheep in the semiarid region of northeastern Brazil. Vet Parasitol. 2016;221:139-43. http:// dx.doi.org/10.1016/j.vetpar.2016.03.027. PMid:27084486.

Vilela VLR, Feitosa TF, Braga FR, Araújo JV, Souto DVO, Santos HES, Silva GLL, Athayde ACR. Biological control of goat gastrointestinal helminthiasis by Duddingtonia flagrans in a semi-arid region of the northeastern Brazil. Vet Parasitol. 2012;188(1-2):127-33. http://dx.doi.org/10.1016/j. vetpar.2012.02.018. PMid:22436426.

Walker HL, Connick WJ Jr. Sodium alginate for production and formulation of mycoherbicides. Weed Sci. 1983;31(3):3338. http://dx.doi.org/10.1017/S0043174500069113.

Willcox HP, Coura JR. Nova concepção para o método de Baermann-Moraes-Coutinho na pesquisa de larvas de nematódeos. Mem Inst Oswaldo Cruz. 1989;84(4):563-5. http://dx.doi.org/10.1590/S0074-02761989000400015. PMid:2487451.

Financial Support: Author declares this study has been exempt of financial support.

Authors Contributions: Vinicius Longo Ribeiro Vilela, Paulo Wbiratan Lopes da Costa, Francisca Flávia da Silva, Hermano Manoel Francisco Figueiredo Bezerra, Leonardo Vinícius Silva de Oliveira, Maysa de Oliveira Dantas, Thais Ferreira Feitosa, Jackson Victor de Araújo and Fabio Ribeiro Braga participated in the writing of the article, considering the reading and review stages. 